\title{
Manajemen program pembelajaran bahasa Arab pada anak prasekolah Yayasan PAUD Sultan Qaimuddin di Kendari
}

\author{
Nur Azaliah Mar *, Danial Hilmi \\ Universitas Islam Negeri Malang \\ Jl. Ir. Soekarno No.1, Dadaprejo, Junrejo, Pendem, Kota Batu, Jawa Timur 65324, Indonesia. \\ * Corresponding Author. Email: nurazaliah.na@gmail.com
}

\section{ARTICLE INFO}

\section{Article History}

Received:

25 December 2020;

Revised:

18 April 2021;

Accepted:

3 May 2021

Available online:

3 May 2021

\section{Keywords}

manajemen program;

bahasa Arab;

anak prasekolah.

program management;

Arabic language;

preschool children.

\begin{abstract}
Penelitian kualitatif deskriptif ini bertujuan mengetahui manajemen program bahasa Arab pada anak prasekolah di Yayasan PAUD Sultan Qaimuddin Kendari. Pengumpulan data menggunakan wawancara pada ketua yayasan, observasi, dan dokumentasi tentang manajemen program bahasa Arab pada anak prasekolah. Penelitian ini menunjukkan bahwa yayasan ini menggunakan fungsi-fungsi kajian manajemen program dalam melaksanakan program pembelajaran bahasa Arab pada anak prasekolah sehingga program ini berjalan efektif dan efisien, yaitu: (1) Perencanaan program pembelajaran bahasa Arab pada anak prasekolah melalui tahap identifikasi kebutuhan, rapat koordinasi, penyusunan program kerja, pelaksanaan program kerja, dan pengawasan. (2) Pengorganisasian di yayasan ini ialah pembina sebagai ketua yayasan yang memegang kekuasaan paling tinggi, dibantu pengurus dan pengawas yayasan, juga pengelola yayasan yang meliputi guru dan tenaga administrasi. (3) Pelaksanaan program pembelajaran bahasa Arab pada anak prasekolah ini yaitu dengan mempersiapkan hal yang berkaitan dengan penentuan guru, pembuatan rencana proses pembelajaran (RPP), penentuan jadwal pembelajaran, dan sarana prasarana yang dibutuhkan. (4) Pengawasan program pembelajaran bahasa Arab ini dilakukan dengan metode langsung.
\end{abstract}

This descriptive qualitative research aims to determine the management programs of Arabic in preschool children at Yayasan PAUD of Sultan Qaimuddin Kendari. Data collection uses interviews with the head of the foundation, observations, and documentation about the management programs of Arabic in preschool children. The results show that the foundation uses the functions of management program studies in implementing Arabic learning programs in preschool children so the program runs effectively and efficiently, namely: (1) Planning the Arabic language program for preschool children through the stages of need identification, coordination meetings, preparation of work programs, implementation of work programs, and supervision. (2) Organization at this foundation is that the founder as chairman of the foundation holds the highest authority and is assisted by official members, supervisors, and organizers, including teachers and administrative staff. (3) Implementation of the Arabic language program for preschool children at this foundation is to prepare the matters related to determining the teachers, making the learning process plan, determining the learning schedule, and required infrastructure. (4) Controlling the Arabic language program in preschool children is carried out in a direct method.

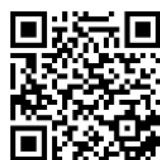

This is an open access article under the CC-BY-SA license.

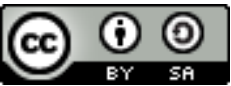

How to cite:

Mar, N., \& Hilmi, D. (2021). Manajemen program pembelajaran bahasa Arab pada anak prasekolah Yayasan PAUD Sultan Qaimuddin di Kendari. Jurnal Akuntabilitas Manajemen Pendidikan, 9(1), 1-10.

doi:https://doi.org/10.21831/jamp.v9i1.36943 


\section{PENDAHULUAN}

Pada era globalisai Pendidikan saat ini, diperlukan manajemen yang efektif dan efisien dalam mengelola suatu program. Manajemen dapat diartikan sebagai pengatur atau pengelola dari segala sumber yang terdiri dari beberapa proses yaitu mulai dari perencanaan, pengorganisasian, pengarahan atau pelaksanaan, dan pengawasan sebagaimana dikemukakan oleh Sisk $(1969$, p. 10) dalam buku Principles of Management, "management is the coordination of all resources through the processes of planning, organizing, directing, and controlling in order to attain stated objectives." Selain itu, pengertian program menurut Arikunto (1998) adalah sederetan rencana kegiatan yang akan dilaksanakan untuk mencapai kegiatan tertentu. Dari kedua pengertian tersebut, maka disimpulkan bahwa manajemen program ialah suatu proses manajemen dalam suatu program pendidikan yang meliputi proses perencanaan, pengorganisasian, penggerakan atau pelaksanaan, dan pengawasan dengan menggunakan sarana dan prasarana yang tersedia agar terwujudnya pendidikan yang lebih efektif dan efisien.

Sebagai suatu organisasi, lembaga pendidikan mempunyai tanggung jawab besar untuk mencerdaskan kehidupan bangsa yang sesuai dengan tujuan pembangunan nasional. Menurut UndangUndang No. 20 Tahun 2003 pada Bab VI Pasal 13 Ayat 1, jalur pendidikan terdiri atas pendidikan formal, nonformal, dan informal yang dapat saling melengkapi dan memperkaya. Pendidikan formal merupakan pendidikan yang memiliki jalur pendidikan teratur dan berjenjang, sedangkan nonformal adalah suatu pendidikan seperti layaknya pelatihan, les privat atau kursus dengan jangka waktu yang relatif singkat atau telah ditentukan. Maka, pendidikan untuk anak prasekolah atau anak usia dini tergolong kepada pendidikan formal yang juga harus dikelola sesuai dengan tahapan manajemen. Konsep manajemen secara umum yang digunakan sama saja dengan konsep manajemen untuk anak usia dini, yaitu upaya untuk mengatur, mengelola, dan mengarahkan interaksi edukatif yang dilakukan antara peserta didik (anak), guru, dan lingkungan baik sekolah maupun masyarakat secara sistematis untuk mencapai tujuan pendidikan yang diinginkan untuk anak.

Dari beberapa Lembaga Pendidikan Prasekolah yang ada di Sulawesi Tenggara, yang terpilih adalah Yayasan PAUD Sultan Qaimuddin Kendari sebagai lembaga pendidikan formal anak prasekolah yang akan diteliti. Yayasan PAUD Sultan Qaimuddin ialah salah satu lembaga yang tergolong pendidikan Islam bagi anak prasekolah dan dituntut untuk melaksanakan program pembelajaran bahasa Arab, adapun yayasan ini mengambil prinsip dasar Kementrian Pendidikan dan Kebudayaan yang berkembang sesuai dengan karakteriktis pendidikan anak usia dini yang berciri khas Agama Islam.

Pendidikan prasekolah pada dasarnya adalah suatu lembaga pendidikan yang bertujuan membantu pertumbuhan serta perkembangan jasmani dan rohani anak di luar dari lingkungan sekitarnya sebelum masuk kepada jenjang yang lebih tinggi yaitu pendidikan dasar (Patmonodewo, 2003). Segala sumber ilmu dan informasi yang didapatkan dalam pendidikan prasekolah bermediakan sebuah bahasa. Jika kemampuan berbahasa anak terhambat, maka berdampak pula kepada akses anak dalam hal informasi dan ilmu ikut terhambat. Anak yang berumur antara tiga sampai lima tahun merupakan anak-anak dalam tahap penguasaan bahasa yang paling kritikal untuk pembelajaran Bahasa, sehingga peneliti bertujuan untuk meneliti suatu manajemen program bahasa Arab pada anak prasekolah yang digunakan pada Yayasan PAUD Sultan Qaimuddin.

Penelitian pada manajemen program untuk anak pernah diteliti oleh Indriani (2018) dengan hasil penelitian sekolah tersebut meraih prestasi yang memuaskan dengan adanya program school garden, karena program ini memperoleh dukungan maupun partisipasi langsung dari warga sekolah. Begitu pula penelitian yang dilakukan oleh Yuniari (2018) yang menemukan bahwa terdapat tiga faktor penghambat program pendidikan dan pelatihan peningkatan kompetensi pengelola PAUD, yaitu (1) keterlambatan peserta, (2) kurangnya kerja sama tim, dan (3) kesiapan materi program diklat peningkatan kompetensi pengelola PAUD.

Letak perbedaan penelitian tersebut dengan pembahasan yang akan dibahas oleh peneliti yaitu pada objek penelitian dan pembahasan yang menitik beratkan pada pembahasan tentang "Manajemen Program Pembelajaran Bahasa Arab pada Anak Prasekolah PAUD Sultan Qaimuddin" dan berfokus pada manajemen program Bahasa Arab. Urgensi kajian manajemen program bahasa Arab pada anak prasekolah di PAUD Sultan Qaimuddin, ialah untuk menjadikan kajian ini sebagai bahan pertim- 
bangan untuk lembaga pendidikan lainnya, baik formal ataupun nonformal yang bergerak di bidang program bahasa, terkait dengan langkah-langkah yang dilakukan dalam manajemen program bahasa Arab, karena sebuah manajemen program dari suatu lembaga pendidikan dapat mempengaruhi kualitas peserta didik di lembaga tersebut. Selain itu, dengan mengetahui manajemen program di PAUD Sultan Qaimuddin diharapkan bisa menjadi barometer awal bagi kalangan yang ingin membuat program pembelajaran yang serupa.

\section{METODE}

Pendekatan penelitian ini menggunakan kualitatif deskriptif. Dalam pembahasan ini peneliti mengolah data yang didapatkan melalui wawancara, observasi, dan dokumentasi tentang program bahasa Arab pada anak prasekolah di yayasan PAUD Sultan Qaimuddin yang dibahas secara mendalam untuk memperoleh kesimpulan sebagai hasil dari penelitian. Wawancara dilakukan dengan informan, yaitu Ketua Yayasan Sitti Kuraedah, dan guru bahasa Arab Linda Asnawati. Keduanya sebagai informan terkait manajemen program bahasa Arab pada anak prasekolah di Yayasan PAUD Sultan Qaimuddin Kendari. Kemudian observasi secara langsung yang dilakukan oleh penelitidan dokumentasi yang didapatkan yaitu berupa dokumen atau data yang berkaitan dengan program bahasa Arab di Yayasan PAUD Sultan Qaimuddin, meliputi visi, misi, serta silabus pembelajaran yang digunakan.

Model Miles and Huberman sebagaimana dijelaskan pada Gambar 1 digunakan sebagai teknik analisis dan pengumpulan data yang terdiri dari tiga langkah yaitu: data reduction, data display, dan conclusion (Sugiyono, 2007). Data reduction didapatkan di lapangan dengan memilih hal-hal penting terkait program bahasa Arab, data display merupakan penyajian data dalam bentuk tabel dan narasi paragraf sehingga menjadi data yang terorganisir, sedangkan conclusion ialah penarikan kesimpulan dari data yang telah dikumpulkan dan terorganisir tentang program bahasa Arab.

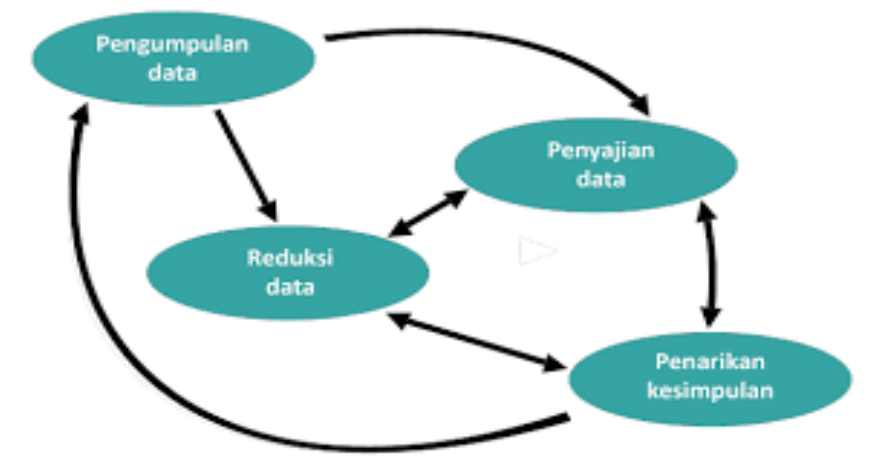

Gambar 1. Pengumpulan Data Model Miles and Huberman

Tujuan akhir dari penelitian ini ialah untuk menjadi dasar dalam mengarahkan kegiatan yang akan dilaksanakan dalam ranah pembelajaran bahasa Arab pada anak prasekolah sehingga hasil yang akan didapat menjadi optimal. Selain itu, penelitian ini mendeskripsikan dan menganalisis tentang proses perencanaan, pengorganisasian, pelaksaanaan, dan pengawasan pada program pembelajaran bahasa Arab pada anak prasekolah PAUD Sultan Qaimuddin di Kendari.

\section{HASIL DAN PEMBAHASAN}

\section{Hasil}

Latar belakang adanya pembelajaran Bahasa Arab pada anak prasekolah Yayasan PAUD Sultan Qaimuddin di Kendari diawali dengan dibentuknya taman kanak-kanak itu sendiri, pada tanggal 30 Juli 2016 dilatarbelakangi keinginan para dosen dari fakultas tarbiyah dan ilmu keguruan di IAIN Kendari untuk membuka TK lab school tempat mahasiswa Program Studi (Prodi) PAUD, Prodi PBA dan Prodi PBI untuk berlatih melakukan pembelajaran di kelas nyata. 
Prodi PAUD sangat membutuhkan tempat berlatih menerapkan ilmu dan metode mengajar yang telah mereka dapatkan, tanpa adanya TK lab school akan sangat menyulitkan untuk mengukur kompetensi dan skill mereka sebagai persyaratan untuk mengikuti Program Praktik Pengalaman Lapangan (PPL). Sedangkan untuk prodi Pendidikan Bahasa Arab memilki mata kuliah ) تعلم اللغة العربية (للأطفال pembelajaran bahasa Arab pada anak, demikian halnya Pendidikan Bahasa Inggris dengan mata kuliah (Teaching English for Young Learners) di mana masing-masing prodi membutuhkan wadah untuk menerapkan ilmu dan metode mengajar yang telah dipelajari. Untuk memenuhi kebutuhan masing-masing prodi maka terbentuklah TK lab school yang menjadi TK yayasan FTIK IAIN Kendari yang diberi nama Yayasan PAUD Sultan Qaimuddin Kendari.

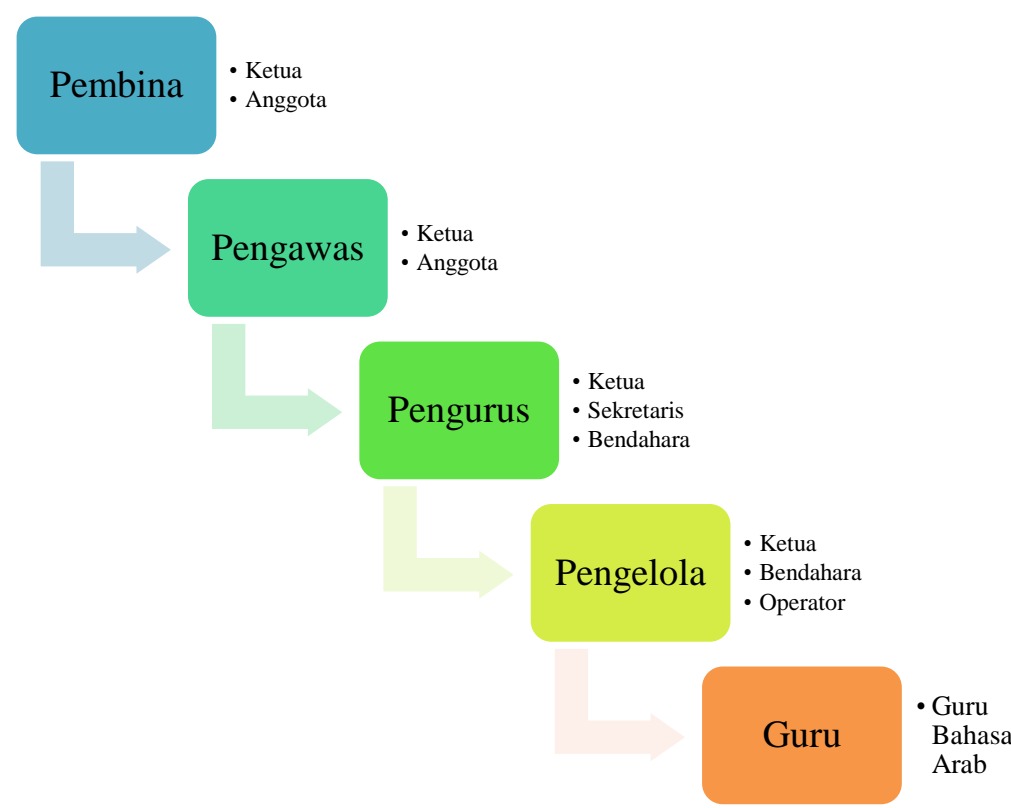

Gambar 2. Struktur Yayasan PAUD Sultan Qaimuddin Kendari

Gambar 2 menjelaskan sebagaimana hasil dari dokumentasi yang telah didapatkan peneliti, struktur organisasi Yayasan PAUD Sultan Qaimuddin Kendari terdiri dari Pembina yaitu ketua yayasan dan anggotanya, Pengurus, Pengawas, dan Pengelola yang meliputi (Kepala TK, Guru, dan Tenaga Administrasi). Adapun silabus program pembelajaran bahasa Arab yang disusun Yayasan PAUD Sultan Qaimuddin Kendari dalam pembelajaran bahasa Arab dijelaskan pada Tabel 1.

Selanjutnya, Kompetensi Inti (KI) dari silabus tersebut antara lain sebagai berikut. KI $1=\mathrm{Me}-$ nerima dan menjalankan agama yang dianutnya. KI $2=$ Memiliki perilaku jujur, disiplin, tanggung jawab, santun, peduli dan percaya diri dalam berinteraksi dengan keluarga, teman dan guru. KI $3=$ Memahami pengetahuan faktual dengan cara mengamati (mendengar, melihat, membaca) dan menanya berdasarkan rasa ingin tahu tentang dirinya, makhluk ciptaan Tuhan dan kegiatannya, dan dan benda-benda yang dijumpai di rumah dan di sekolah. KI 4 = Menyajikan pengetahuan faktual dalam bahasa yang jelas dan logis, dalam karya yang estetis, dalam gerakan yang mencerminkan anak-anak sehat, dan dalam tindakan yang mencerminkan perilaku anak beriman dan berahklak mulia.

Berdasarkan hasil yang didapatkan di lapangan dan analisis data yang dilakukan, maka manajemen program di dalam sebuah organisasi pendidikan dilaksanakan agar penyelenggaraan kegiatan berjalan dengan sistematis dan dapat dievaluasi sehingga program itu bisa menjadi lebih efektif dan produktif. Begitu pula dengan program bahasa Arab pada anak prasekolah membutuhkan sebuah manajemen program sehingga pembelajaran bahasa Arab menjadi sistematis.

Yayasan PAUD Sultan Qaimuddin Kendari merupakan lembaga pendidikan yang mengkhususkan pembelajaran kebahasaan khususnya bahasa Arab. Bahasa ialah sebuah aspek yang sangat penting untuk masa depan anak. Apalagi saat ini bahasa digunakan sebagai media komunikasi pada era komunikasi global, baik itu bahasa Indonesia, Inggris, maupun Arab, oleh karena itu, pengembangan kemampuan bahasa sedini mungkin dilaksanakan. 
Tabel 1. Silabus Pembelajaran Bahasa Arab di Yayasan PAUD Sultan Qaimuddin Kendari

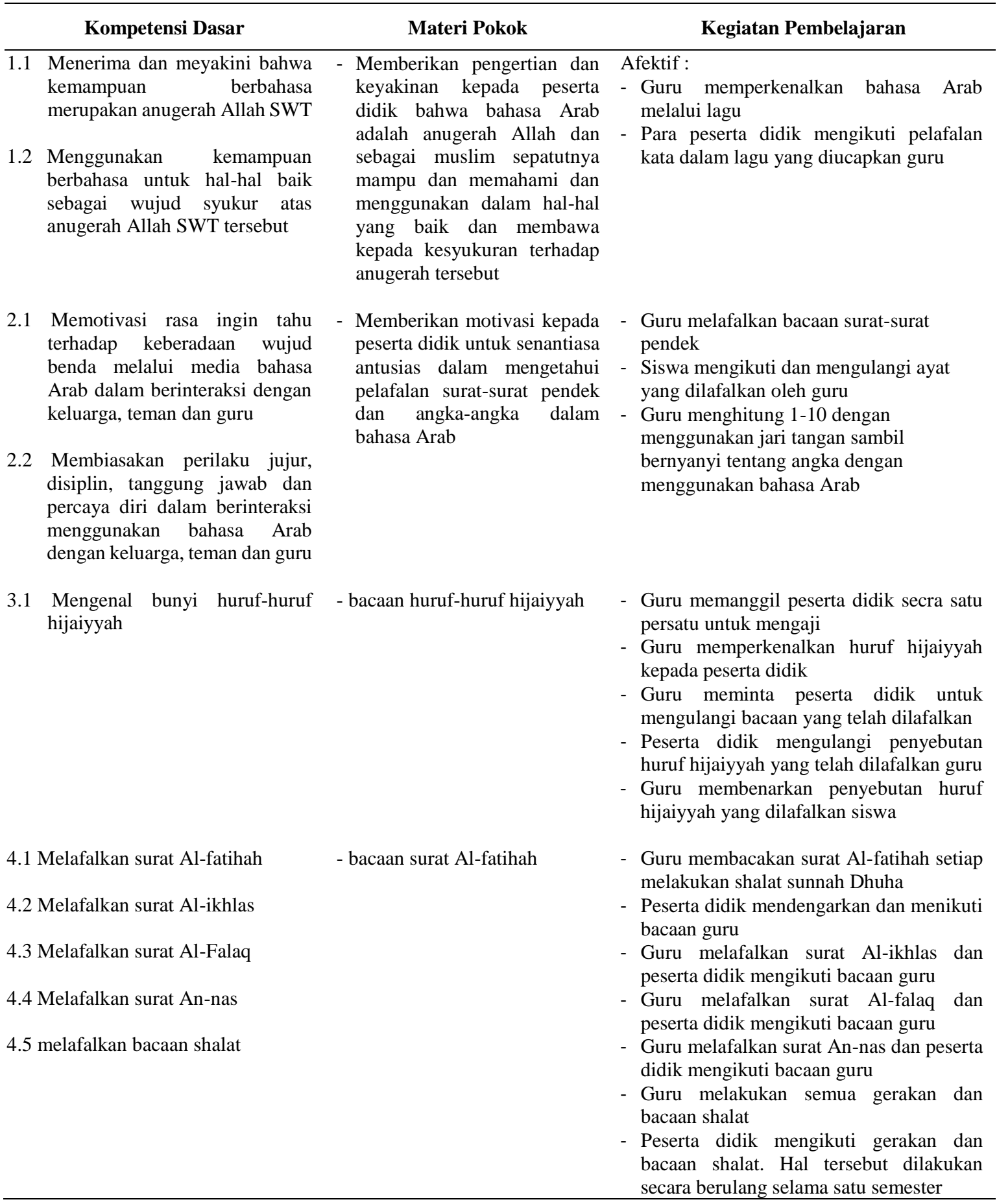

Bahasa, sebagaimana dikemukakan oleh Jamian (2010), adalah sebuah alat untuk menyampaikan informasi atau pesan yang mempunyai makna tertentu kepada individu lain agar dapat dipahami maksud dan tujuannya. Sebuah lembaga pendidikan dituntut untuk mengajarkan beberapa bahasa asing dalam lembaga tersebut untuk memperkaya bahasa anak. Salah satu pembelajaran bahasa yang berciri khas Agama Islam adalah bahasa Arab. Menurut Al-Muslim dan Zamri (2012), bahasa Arab dianggap sebagai salah satu bahasa tertua dunia yang dikelompokkan dalam bahasabahasa semantik. Perkembangan dan peredaran masa telah meletakkan bahasa Arab sebagai salah satu bahasa utama dunia. 


\section{Pembahasan}

Konsep manajemen menurut Sagala (2009, p. 140) ialah tindakan dan usaha yang dilakukan oleh kepala sekolah selaku pemimpin struksional di sekolah, maupun yang dilakukan oleh guru sebagai penuntun dalam proses pembelajaran di kelas untuk mendapatkan hasil pencapaian tujuan program sekolah. Adapun fungsi dari manajemen yang diterapkan dalam program ini dijelaskan sebagai berikut.

\section{Perencanaan}

Perencanaan (planning) sebagai salah satu proses dari fungsi manajemen dalam penyusunan keputusan pekerjaan yang akan dikerjakan di kemudian hari demi tercapainya tujuan yang diinginkan. Maka dari itu, perencanaan ialah proses penetapan upaya yang akan dilaksanakan dan pemanfaatan sumber daya secara terpadu yang dapat menunjang kegiatan dalam mencapai tujuan yang efektif dan efisien.

Proses dari perencanaan program bahasa Arab pada anak prasekolah Yayasan PAUD Sultan Qaimuddin Kendari sebagaimana hasil wawancara dengan ketua yayasan pada tanggal 1 November 2019 bahwa ketika merekrut tenaga pengajar, PAUD ini merekrut salah satu tenaga pengajar dengan kualifikasi lulusan bahasa Arab untuk mengkhususkan pembelajaran bahasa Arab diajarkan oleh guru tersebut, agar pembelajaran bahasa Arab pada anak prasekolah menjadi lebih efektif. Adapun indikator yang dipakai dalam tahap perencanaan meliputi hal-hal sebagai berikut.

\section{Identifikasi Kebutuhan}

Identifikasi dapat diartikan sebagai suatu proses menganalisis sumber yang menimbulkan sebuah dorongan untuk mengadakan suatu program. Hasil dari identifikasi kebutuhan yang didapatkan akan menghasilkan informasi dan data mengenai hal-hal yang berhubungan dengan pengetahuan dan ketrampilan yang berhubungan dengan kebutuhan masyarakat (Basri, 2015, p. 35).

Identifikasi kebutuhan pada program pembelajaran bahasa Arab melibatkan banyak unsur, meliputi; semua Pembina baik ketua maupun anggota, Pengurus, Pengawas dan pengelola PAUD. Kebutuhan yang ingin dipenuhi yaitu agar adanya wadah untuk prodi PAUD, PBA, dan PBI Fakultas Tarbiyah dan Keguruan untuk mengaplikasikan ilmu dan metode mengajar yang didapatkan dalam kelas secara langsung kepada anak prasekolah.

\section{Perencanaan Kurikulum}

Peraturan Pemerintah No. 66 Tahun 2010 pada perubahan atas PP No. 17 Tahun 2010 tentang pengelolaan dan penyelenggaraan pendidikan menyatakan bahwa kurikulum ialah seperangkat rencana yang akan dikerjakan oleh tenaga pendidik, di dalamnya meliputi pengaturan tentang tujuan, isi, dan bahan ajar, serta cara yang akan digunakan dalam proses belajar mengajar sebagai pedoman penyelenggaraan dalam pencapaian tujuan dari pendidikan.

Teori yang dirujuk menunjukkan perencanaan kurikulum dalam sebuah perencanaan program Bahasa Arab yakni tidak ada kurikulum tersendiri dalam penyusunan kurikulum melainkan berpedoman pada kurikulum PAUD dari Peraturan Pemerintah mengenai standar PAUD untuk acuan dalam menyusun silabus terkait materi yang akan diberikan pada anak prasekolah. Menurut Ali (2015), perencanaan pembelajaran selalu dibuat sebelum awal tahun pelajaran dimulai yang dikemas dalam kegiatan rapat kerja.

\section{Perencanaan Instruktur dan Fasilitator}

Pendidik merupakan seorang tenaga pengajar atau kependidikan yang memiliki kualifikasi seperti guru, dosen, tutor, instruktur, konselor, fasilitator atau panggilan lainnya yang sesuai dengan pekerjaannya atau keahliannya. Perencanaan instruktur atau fasilitator pada program pembelajaran bahasa Arab mempunyai kriteria atau persyaratan yang khusus yaitu lulusan S-1 jurusan bahasa Arab. 


\section{Perencanaan Sarana Prasarana}

Sarana dan prasarana yang akan digunakan dalam program Bahasa Arab secara keseluruhan harus disediakan sedemikian rupa dan terpenuhi selama proses pembelajaran berlangsung, baik dari ruang pembelajaran, bahan ajar, dan lain sebagainya. Perencanaan keuangan dan sarana prasarana untuk terlaksananya program pembelajaran bahasa Arab pada anak prasekolah di Yayasan PAUD Sultan Qaimuddin Kendari telah direncanakan dan dipersiapkan dalam rencana jangka menengah dan jangka pendek.

Berdasarkan penjelasan tersebut, peneliti menyimpulkan bahwa perencanaan pada program bahasa Arab melibatkan banyak pihak yang memiliki tanggung jawab besar, diantaranya pendidik sebagai sumber ilmu utama, serta pengawas untuk menunjang kesuksesan pelaksanaan program pembelajaran ini. Di sisi lain, tahapan perencanaan pada program ini dimulai dari: (1) identifikasi kebutuhan serta memikirkan bagaimana kondisi lingkungan tempat belajar dan juga peserta didik yang diinginkan ke depannya, (2) rapat koordinasi, (3) penyusunan program kerja, (4) penggerakan atau pelaksanaan program, yakni realisasi program kerja yang telah disusun, serta melakukan pengawasan, juga (5) evaluasi, yang dilaksanakan demi tercapainya tujuan program bahasa Arab secara efektif dan efisien.

Pada dasarnya, segala sesuatu yang sistematis dalam berbagai bidang kehidupan manusia tidak luput dari sebuah proses perencanaan, termasuk bidang pendidikan. Maka, proses perencanaan akan selalu ada dalam proses manajemen suatu kegiatan, lembaga maupun organisasi yang akan diselenggarakan.

\section{Pengorganisasian}

Pengorganisasian (organizing) (Karyoto, 2016, p. 67) ialah suatu kegiatan yang dilakukan oleh manajer untuk menciptakan kerja sama antara para pekerja sehingga semua pekerjaan dapat diselesaikan dengan efektif dan efisien guna mewujudkan tujuan yang ingin dicapai dalam organisasi di masa depan. Pengorganisasian dapat didefinisikan sebagai proses penetapan pada suatu pekerjaan yang efektif untuk dikerjakan, pembagian pekerjaan yang sesuai dengan bagian kerjanya dikelompokkan agar mencapai tujuan yang diinginkan. Proses pengorganisasian dalam suatu program dimulai dengan menyusun struktur, tugas pokok dan fungsi tiap divisi yang telah tersusun, visi dan misi serta tujuan dari Yayasan PAUD Sultan Qaimuddin Kendari, dan pengorganisasian pembelajaran yang dilaksanakan mulai dari penyusunan silabus dan RPP.

Visi Yayasan PAUD Sultan Qaimuddin Kendari adalah "Menjadi lembaga pendidikan anak usia dini yang unggul, kompetitif, dan berdaya saing untuk menciptakan generasi yang cendekia dan berkarakter". Demi mewujudkan visi tersebut, maka telah dirumuskan enam poin misi, yang dijabarkan sebagai berikut. (1) Meningkatkan mutu pendidikan yang unggul dan terpadu melalui kegiatan bermain sambil belajar. (2) Menanam ajaran agama untuk memiliki keimanan dan ketaqwaan melalui pembiasaan. (3) Menjadikan kegiatan bermain sebagai sarana penanaman nilai-nilai moral untuk generasi yang berkarakter di masa depan. (4) Menjadikan metode demonstrasi dan keteladanan sebagai media menumbuhkan karakter anak didik. (5) Mengembangkan pola pikir anak yang imajinatif, terbuka dan memiliki rasa ingin tahu melalui kegiatan bermain sambil belajar di kelas. (6) Membiasakan anak untuk selalu beribadah sehingga terbentuk karakter yang cerdas, sehat dan ceria.

Ketika serangkaian visi dan misi telah terbentuk, maka proses selanjutnya adalah mencanangkan program-program yang terstruktur guna mendukung terwujudnya visi yang telah ditetapkan tersebut. Adapun tujuan dari Yayasan PAUD Sultan Qaimuddin Kendari adalah sebagai berikut: (1) mewujudkan lembaga PAUD yang unggul dan kompetitif dengan layanan bermain sambil belajar kepada peserta didik, (2) mewujudkan peserta didik yang mempunyai sikap iman dan taqwa sesuai ajaran agama dalam keseharian, (3) mewujudkan generasi yang berkarakter di masa depan melalui penanaman moral sejak usia dini, (4) mewujudkan karakter melalui pembinaan dari pendidik dan tenaga kependidikan, dan (5) mewujudkan anak dengan kemampuan imajinasi dan rasa ingin tahu yang tinggi. 


\section{Pelaksanaan}

Penggerakan atau pelaksanaan (directing) ialah suatu tindakan, upaya, ataupun usaha pimpinan dalam memberikan motivasi dan dorongan kepada individu yang dipimpin dalam mengarahkan pekerjaan dan perbuatan yang dikerjakan dengan menggunakan potensi yang ada dalam dirinya guna tercapainya sebuah tujuan yang telah ditetapkan (Sudjana, 2004, p. 150). Gerakan dari kegiatan pertama yaitu perencanaan dan kedua pengorganisasian ialah salah satu bentuk dari fungsi pelaksanaan (Amtu, 2013). Fungsi pelaksanaan ditekankan kepada terciptanya kerja sama dan tanggung jawab antar anggota dalam suatu lembaga ataupun organisasi, serta penekanan pada tingkat semangat dan minat dalam bekerja oleh keseluruhan anggota demi pencapaian tujuan organisasi.

Fungsi pelaksanaan dalam program bahasa Arab adalah suatu tahap untuk merealisasikan sebuah rancangan program yang telah disusun pada tahap perencanaan program. PAUD Sultan Qaimuddin mempersiapkan beberapa hal yang berkaitan dengan pelaksanaan program dalam tahap ini yaitu menentukan guru yang akan mengajarkan bahasa Arab, menentukan jadwal pembelajaran, menyusun rencana proses pembelajaran (RPP), dan menyediakan sarana prasarana yang akan digunakan dalam pelaksanaan program pembelajaran bahasa. RPP yang akan digunakan disusun oleh guru pengajar bahasa Arab sebagai rancangan dalam pelaksanaan pembelajaran sehingga guru menjadi lebih maksimal dalam menjalankan tugasnya. Sedangkan jadwal program pembelajaran bahasa Arab diatur oleh pengelola yayasan PAUD. Dengan demikian, pelaksanaan program bahasa Arab menjadi terarah menuju tercapainya tujuan dari program.

Berdasarkan hasil observasi dalam pelaksanaan program bahasa Arab, anak prasekolah aktif dalam pembelajaran. Pelaksanaan pembelajarannya seperti mengajarkan anggota tubuh bahasa Arab melalui nyanyian dengan penyebutan yang benar seperti layaknya penutur Arab asli. Adapun pembelajaran dilaksanakan dalam kelas kecil yang berisi maksimal sembilan orang sehingga ilmu yang diserap oleh anak lebih maksimal, karena jumlah anak pada PAUD tersebut adalah 17 orang dan dibagi ke dalam dua kelas dimana masing-masing kelas ada yang delapan orang dan ada pula yang sembilan orang. Adapun kelas yang digunakan lengkap dengan papan tulis dan lain sebagainya.

\section{Pengawasan}

Pengawasan (controlling) menurut Admosudirjo (Kamil, 2012, p. 63) merupakan keseluruhan daripada kegiatan yang membandingkan atau mengukur apa yang sedang atau sudah dilaksanakan dengan kriteria, norma, standar, atau rencana yang telah ditetapkan sebelumnya. Pengawasan dilaksanakan dengan menggunakan teknik observasi. Ketua Yayasan melakukan pengawasan terhadap pengelola yayasan. Untuk mengetahui etos kerja guru dalam proses belajar mengajar baik dalam kelas maupun luar kelas, maka dilakukan pengawasan dengan supervisi oleh pengelola yayasan agar menjadi evaluasi bagi program lain kedepannya. Dalam hal ini pengawasan ialah peninjauan kembali program kerja yang telah dilaksanakan, tahap ini dilakukan oleh pengelola yayasan yang bertujuan untuk mempertahankan dan meningkatkan kualitas program bahasa Arab pada anak prasekolah, sedangkan guru diberikan tanggung jawab besar untuk mengawasi siswanya ketika pembelajaran sedang berlangsung.

Proses pengawasan yang dilakukan dalam program bahasa Arab pada anak prasekolah di Yayasan PAUD Sultan Qaimuddin Kendari bersifat langsung, yang berarti bahwa pengelola yang turun langsung dalam mengawasi kegiatan yang berlangsung dan apabila ada yang kurang berkenan maka pengelola langsung memberi tahu atau menegur guru agar tidak terjadi lagi untuk kedua kalinya, dan agar kualitas program kedepannya dapat meningkat dan lebih baik lagi. Menurut Murdick (Fattah, 2004), pengawasan ialah suatu proses mendasar yang sangat dibutuhkan dalam suatu lembaga atau organisasi. Penentuan baik atau buruknya suatu rencana program dilihat dari hasil pengawasan, maka pengawasan harus dilakukan dengan sebaik-baiknya agar menghasilkan rencana program yang baik pula.

Pengawasan juga bisa diartikan sebagai proses pengukuran dan penilaian (Amtu, 2013), pengukuran yang dimaksud ialah pada tingkat pengelolaan kerja anggota dan penggunaan sarana kerja yang meningkat efisiensinya dalam memberikan kontribusi terhadap pencapaian tujuan organisasi. Tujuan dari pengawasan menurut Kurniadin dan Machali (2012) ialah untuk menciptakan sua- 
sana yang transparan tanpa ada yang disembunyikan, untuk mencegah adanya kesalahan, dan untuk meningkatkan kinerja organisasi.

Selain itu, Handoko (2008, p. 142) menyatakan bahwa pengawasan adalah memberikan masukan dan mengevaluasi tentang penyampaian rencana dan standar serta penilaian hasil pekerjaan dengan memasukkan dan mengeluarkan solusi yang dihasilkan, maka pengawasan dilanjutkan dengan evaluasi. Pelaksanaan kegiatan dievaluasikan dari segala penyimpangan yang tidak diinginkan dalam program untuk langsung diperbaiki agar mencapai tujuan yang baik.

Kegiatan dalam proses evaluasi meliputi: (1) penyusunan rencana evaluasi, (2) proses evaluasi dilakukan oleh pengelola, (3) pengolahan dan penganalisisan data, (4) pengadaan rapat untuk menghasilkan solusi dari masalah yang ditemukan, agar di program lainnya tidak terjadi hal yang sama dan program klain bisa menjadi lebih baik. Kegiatan evaluasi juga menghasilkan Informasi yang tepat dan akurat (Wiyono dan Sunarni, 2009).

Pada hakikatnya, evaluasi ialah suatu proses yang dilakukan secara sistematis dan berkelanjutan untuk menentukan kualitas dari sesuatu, yang berdasarkan dari pertimbangan dan kriteria tertentu untuk pengambilan keputusan (Kurniadin dan Machali, 2012). Seperti halnya dalam suatu program dilakukan evaluasi untuk menentukan nilai dan arti dari kualitas program tersebut, tujuan dari evaluasi itu sendiri ialah untuk memperoleh dasar pertimbangan, menjamin cara kerja yang efektif dan efisien, serta memperoleh solusi atas hambatan yang dialami oleh lembaga atau organisasi dalam menjalankan suatu program.

Berdasarkan hasil observasi, dapat disimpulkan bahwa proses pengawasan program pembelajaran bahasa Arab sejalan dengan teori evaluasi yang dipaparkan sudah berjalan dengan sesuai. Pengawasan dalam program ini dilakukan oleh pengelola, yaitu dalam hal meninjau kembali program kerja yang telah dilaksanakan, di mana pengawasan ini bertujuan untuk mempertahankan dan meningkatkan program bahasa Arab yang telah dilakukan.

Sementara itu, proses evaluasi program memiliki empat tahapan, yaitu dimulai dari penyusunan rencana evaluasi, pengawasan, pengolahan data, dan rapat perbaikan, di mana keempatnya dilakukan untuk menentukan kualitas dari suatu program, berdasarkan atas pertimbangan, dan kriteria tertentu dalam rangka pengambilan keputusan. Hasil dari evaluasi program bahasa Arab pada anak prasekolah yayasan PAUD Sultan Qaimuddin ialah program bahasa Arab pada anak prasekolah ini sudah berjalan sesuai dengan visi, misi, dan tujuan dari progam, akan tetapi kurangnya divisi marketing untuk memasarkan PAUD ini yang mengakibatkan jumlah siswa pada yayasan Sultan Qaimuddin masih terbilang minim. Dengan banyaknya siswa akan menambah individu yang diajarkan berbahasa Arab, maka hal ini sebagai bahan rencana program kerja yang akan dilaksanakan untuk meningkatkan kualitas program yang akan dilaksanakan setelahnya.

\section{SIMPULAN}

Dari hasil penelitian yang diperoleh dari pembahasan tentang manajemen program pembelajaran bahasa Arab pada Anak Prasekolah Yayasan PAUD Sultan Qaimuddin di Kendari, disimpulkan bahwa untuk mencapai terwujudnya program Bahasa Arab pada Anak Prasekolah yang efektif dan efisien, maka pengelola Yayasan harus mengaplikasikan fungsi-fungsi manajemen program tersebut agar terhindar dari penyimpangan visi dan misi yang telah ditentukan yang berlandaskan: (1) perencanaan program Bahasa Arab pada Anak Prasekolah yang terdiri dari mengidentifikasi kebutuhan, pengadaan rapat koordinasi, penyusunan program kerja, pelaksanaan program, pengawasan, serta evaluasi; (2) pengorganisasian, pembina sebagai pemegang kekuasaan paling tinggi, lalu dibantu oleh pengurus dan pengawas yayasan dan juga pengelola sekolah yang meliputi guru dan tenaga administrasi; (3) pelaksanaan program yaitu dengan mempersiapkan hal-hal yang berkaitan langsung dengan proses pelaksanaan program, seperti penentuan guru yang akan mengajar, penentuan jadwal pembelajaran, pembuatan rencana proses pembelajaran (RPP) oleh guru, dan penyediaan sarana prasarana yang akan digunakan dalam proses pelaksanaan program pembelajaran bahasa; (4) pengawasan program bahasa Arab pada anak prasekolah yang bersifat langsung, yaitu pengelola turun tangan langsung dalam mengawasi kegiatan program bahasa Arab pada anak prasekolah. 


\section{DAFTAR PUSTAKA}

Al-Muslim, M., \& Zamri, A. (2012). Pengajaran dan pembelajaran bahasa Arab: Satu tinjauan literatur di Negeri Sembilan. Persidangan Kebangsaan Pengajaran Dan Pembelajaran Bahasa Arab 2012 (PKEBAR'12), 278-285.

Ali, M. (2015). Implementasi model manajemen berbasis sekolah (MBS) di SMA Negeri 2 Unggulan Sangatta Utara. Syamil: Jurnal Pendidikan Agama Islam, 3(2), 303-338. https://doi.org/10.21093/sy.v3i2.247.

Amtu, O. (2013). Manajemen pendidikan di era Otonomi Daerah. Alfabeta.

Arikunto, S. (1998). Penilaian program pendidikan. Bima Aksara.

Basri, H. (2015). Manajemen pendidikan dan pelatihan. Pustaka Setia.

Fattah, N. (2004). Landasan manajemen pendidikan. PT Remaja Rosdakarya Offset.

Handoko, T. H. (2008). Manajemen personalia dan sumber daya manusia ( $2^{\text {nd }}$ ed.). BPFE Yogyakarta.

Indriani, R. (2018). Manajemen program School Garden guna mewujudkan sekolah Adiwiyata. Jurnal Manajemen Dan Supervisi Pendidikan, 2(2), 89-96. https://doi.org/10.17977/um025v2i22018p089.

Jamian, A. R. (2010). Keupayaan kanak-kanak prasekolah menguasai ayat bahasa Melayu. Jurnal Linguistik, $\quad 11(1), \quad 1-14 . \quad$ Retrieved from https://plm.org.my/ejurnal/index.php/jurnallinguistik/article/view/148.

Kamil, M. (2012). Model pendidikan dan pelatihan (konsep dan aplikasi). Alfabeta.

Karyoto, K. (2016). Dasar-dasar manajemen (Teori, definisi, dan konsep). Andi.

Kurniadin, D., \& Machali, I. (2012). Manajemen pendidikan: Konsep \& prinsip pengelolaan pendidikan. Ar-Ruzz Media

Patmonodewo, S. (2003). Pendidikan anak prasekolah. Rineka Cipta.

Peraturan Pemerintah (PP) No. 66 Tahun 2010 tentang Perubahan Atas Peraturan Pemerintah Nomor 17 Tahun 2010 Tentang Pengelolaan Dan Penyelenggaraan Pendidikan. (2010).

Sagala, S. (2009). Konsep dan makna pembelajaran: Untuk membantu memecahkan problematika belajar dan mengajar. Alfabeta.

Sisk, H. L. (1969). Principles of management: A systems approach to the management process. South-Western Publishing Company.

Sudjana, D. (2004). Manajemen program pendidikan: Untuk pendidikan nonformal dan pengembangan sumber daya manusia. Falah Production.

Sugiyono, S. (2007). Metode penelitian kuantitatif, kualitatif, dan R\&D. Alfabeta.

Undang-Undang No. 20 Tahun 2003 tentang Sistem Pendidikan Nasional. (2003).

Wiyono, B. B., \& Sunarni, S. (2009). Evaluasi program pendidikan dan pembelajaran. Fakultas Ilmu Pendidikan Universitas Negeri Malang.

Yuniari, D. D. (2018). Manajemen program pendidikan dan pelatihan peningkatan kompetensi pengelola PAUD di BP-PAUD dan Dikmas Jawa Timur. J+PLUS UNESA: Jurnal Mahasiswa Pendidikan Luar Sekolah Universitas Negeri Surabaya, 7(1), 1-8. Retrieved from https://jurnalmahasiswa.unesa.ac.id/index.php/jurnal-pendidikan-luarsekolah/article/view/24128. 